\title{
Identification of the main problems in social work with low-income families
}

\author{
A. Bánovčinová and K. Levická \\ Trnava University in Trnava, Trnava, Slovakia
}

\begin{abstract}
Family is a basic social group, which influences one 's life in all its stages. Through optimal fulfilment of functions which are imposed by society, it creates a safe environment for survival and development of family members. It is an essential factor in socializing and significantly affects the social functioning of its members. The family is also a dynamic system whose functioning operates a number of internal but also external factors. One of these factors is family income. The aim of our study is to investigate which dimensions and aspects of family functioning are threatened by living below the breadline. For assessing individual dimension of family functioning we used the Family Assessment Device (FAD). Quantitative analysis showed disruption of the functioning of the family system in all dimensions. The greatest family disruption was found in dimensions of role, behaviour control and affective involvement.

Poverty is a social problem that negatively affects all dimensions of family system functioning. In order to provide effective help and intervention to the family, it is essential that the social worker is able to correctly identify problem areas and appropriately choose methods and procedures aimed at restoration of family functioning.
\end{abstract}

\section{Introduction}

In the life of the individual, the family represents the primary and key social group. Significantly it affects the process of socialization. In the family one learns the rules and behaviour standards of the society, takes specific behaviour patterns. Johnson [1] draws our attention to the importance of the family in creating immediate environment by providing sufficient incentives for the development, particularly at younger age. He pointed out that the family operation can positively or negatively affect the child's school results and social competence [2]. On the other hand, children from families with a standard income have better access to resources and incentives needed for their optimal development, while children from low-income families have limited access [2]. Becker [3] emphasises that these sources cannot be perceived only by means of market value and costs for quality care. The investment of a parent is also the value of time.

Likewise, Havemen and Wolfe [4] came to similar conclusions, and further they discovered worse school results of children from economically disadvantaged environment. After completion of their education they experience difficulties with employment in the labour market [5]. In addition to the overall family functioning, it is possible to identify other factors within the family that also correlate with social and academic success of a child. Gullesserian [2] includes in these factors a set of the family system, family personal growth, parental distress, family constellations, socioeconomic status and employment status of parents. Walsh [6], discussing the issue of family functioning, also points to the importance 
of family structures. Families with different designs have different structural conditions and operation resources. For example, families where both parents work must organize their household and, in particular the role of its members, thus their family life differs from that of the families with unemployed members. Similarly, single parents must put more effort on organization of work and family life. Families after divorce must help children move between two households so that they feel at home in each of them and are able to adapt to changes.

All these factors are closely related to the overall functioning of the family system and largely affect not only the ability of family members to cope with the requirements and demands of the family, but also the environment in which the family lives. Optimally functioning family is not only important for children and young people. Functional family system also has an impact on the functions of an elderly person. Johnson [1] describes three features of a sound family. Family members are the main source of social integration of an elderly relative. They may also indirectly contribute to the intellectual development of an elderly person through the enrichment of its social environment. The family is also the primary provider of social support for many elderly people, who experience a decline in physical and mental abilities. The family also can potentially contribute to the minimization of decrease in intellectual functioning of the elderly person and provides normative anchoring that reinforces social conventions and expectations about appropriate behaviour. The involvement of the family can help the elderly person to become familiar with the facts and thus alleviate the increased eccentricity, forgetfulness and confusion. Hence the key factors, influencing the functioning of the family members, comprise the whole system. Family functioning is a more specific construct compared to families' coping styles. Experts point to the fact that family functioning plays a significant role in parental stress [TheatreDeckard, In 7]. Also commissioning authors and Klever [8] combine a family operation with a complete response to the presence of family stressor.

Family life cannot be reduced to the level of one dimension. The functioning of the individual, as well as family functioning involves many processes associated with biological and environmental influences [6].

Currently there is not a consensus on basic dimensions of the family functioning. Specification of dimensions and key areas of family functioning vary depending on the specialization of author of given concept or model. Skinner, Steinhauer and Santa-Barbara [9] are the authors of the evaluation model of family functioning, which is based on seven dimensions: task accomplishment, role performance, communication, affective expression, affective involvement, control and values and norms. The authors of this model based on the notion that the family provides basic biological, psychological and social elements to ensure its permanence. In pursuing the objectives of the family, the family members have to deal with maintenance, development and crisis task. These tasks vary depending on the cycle of family life. Another view of the family is the approach assessment of family strengths. Authors of this approach are Orthner, Jones-Sanpei and Williamson [10]. Their model considered six dimensions: economic stability communication skills, problem-solving skills, family cohesion, social support and the presence of risk factors. The outcome of this assessment demonstrates that the economic insecurity, which families are confronted with, correlates with lack of problem-solving skills and eroded family cohesion. Furthermore, the analysis also discovered considerable differences in communication skills and providing social support in observed families with low income.

The functioning of families in the various dimensions is influenced by multiple factors. As already mentioned, one of these factors is also the socioeconomic status of the family. In literature the concept of socio-economic status and its measurement is associated with 
education, occupation, family structure and family income. These indicators are represented by three types of resources: human, financial and social capital [2].

In our study we focus on family income, which affects the forfeiture of families into poverty and its impact on the functioning of the family system. The issue of poverty is in contemporary society more acute, because the research generally shows its rising trend. The ability of families to fulfil an economic function is influenced by several factors. Among the most important we include employment status of economically active household members, family structure and its demographic composition, educational attainment of the household head, ethnicity of household members and the location in which the household is located. Likewise, the report of the EU-SILC shows that the profile of poverty in Slovakia is the result of a number of indicators such as the economic activity of persons, the structure and size of the household, but also age and regional differences [11].

The National social report for the year 2012 [12] shows that there is a significant increase in the number of people living in households with very low intensity of work within individual indicators. These families are one of the groups at highest risk, in terms of the fall into poverty. Wages for performed work activities is, in most cases, the main or even the only source of funding that the family has. This income helps to secure adequate living standards of families and meet the needs of individual members. Job loss is therefore highly stressful and difficult situation. Significantly, it affects changes in the prior way of life of a particular unemployed individuals, but also entire families. Unemployment, and thus the loss or reduction of income to households, causes fall in living standards of families struggling to satisfy certain needs. Payment of housing costs can also be a problem, and can result in growth of debts on rent, electricity and so on. However, a similar situation may also occur if the individual is employed, but on a position where salary is equal to or only slightly exceeds a minimum wage. In this case, the family can get in a difficult situation, as the reception on one side exceeds States defined the poverty line and therefore are not eligible for assistance from the state, on the other hand, real family income is insufficient to satisfy all its needs.

The economic situation of families is largely affected by the number of its members, and especially those economically active. Based on the findings of the Statistical Bureau of SR, households, most endangered by poverty, are predominantly those with two adults and with three or more dependent children. $28.4 \%$ of them were endangered by the risk of poverty. The next risk group were one-parent households with at least one dependent child, thus incomplete families (30.6\%) [11]. Majority of single parent families have recently resulted from divorce. Another, not so frequent, reason is the death of a parent or child birth to single mothers. Incomplete or one parent families are at risk of socio-economic problems and poverty exposed to a much greater extent than is the case with complete families. The basic determinants of socio-economic situation of poor single-parent families is their low or absent income. Statistics show that $90 \%$ of single-parent families households are headed by mother, while working incomes of women are generally lower than those of working men. They must also address the problem in reconciling working time with family obligations [13].

Another factor influencing socio-economic status of the family is the educational attainment of the household head. Education is, according to Gerberyho, Bodnárová and Filadelfiová [14], the strongest safeguard against poverty. In general we can say that the lower the education level, the higher the degree of risk of socio-economic problems and poverty as such. This is because the level of education and level of qualifications of the individual directly influences their labour market position and also his grade and consequently salary. People with little education often face problem of employment due to a lack of qualification, or even if they work, their salary is around statutory minimum. 
The risk of poverty as well as poverty as such is more frequent among ethnic groups than the majority population. This, according to Mares [15] does not appear just as job insecurity, low income or unemployment, but also has a broader disadvantages, such as the reduction of life chances, lower quality of life, inequality in access to medical care.

\section{Methodology}

In order to achieve our objectives and evaluate the functioning of the family system, we took into consideration the McMaster model of family functioning. The model is based on system theory and its crucial assumptions are: (1) All parts of the family are mutual; (2) One part of the family cannot be understood in isolation from the rest of the family system; (3) Overall picture of family functioning cannot be created in a simple reduced understanding of each individual family member or subgroup; (4) Family structure and organization are important factors that strongly influence and determine the behaviour of family members; (5) Transactional patterns of family system strongly form the behaviour of family members.

In order to assess family functioning, similarly to the McMaster model, we concentrated on 6 dimensions of family life: problem solving, communication, family roles, affective reactions, affective involvement, and control of behaviour. As noted by Epstein et al. [16], in order to fully understand such a complex entity as a family, it is necessary to evaluate many dimensions. However, the dimensions in our chosen models are not exhaustive calculation of all aspects of family functioning. The authors describe only those considered important in the clinical context. Their goal was to conceptualize the dimensions in a way that would allow their easy and helpful usage in research.

Purpose of the study: Determine whether poverty affects the family functioning in all its dimensions and identify the most affected dimensions.

\section{Participants}

The sample consisted of 620 participants divided into two groups. The first group consisted of 310 participants (mean age $=32.05 \pm 15.57$, range $=11-67$ ) living in families with income below the level of subsistence minimum. The subsistence minimum in the Slovak Republic is recognized by the state as a poverty line. The second group was control group consisted of 310 participants (mean age $=34.24 \pm 16.10$, range $=11-82$ ) living in families with income standard.

\section{Measures and procedure}

In order to evaluate family functioning, Family Assessment Device ( FAD) questionnaire was used. It is a 60-item self-assessment tool. It is designed to assess selected dimensions of family functioning and is based on the McMaster model of family functioning. Assessed dimensions are: (a) problem solving - family's ability to solve problems at a level that maintains effective family functioning, (b) communication - the way the family exchanges information (emphasis is put on verbal exchange), (c) roles - repeating patterns of behaviour by which individual members perform family functions, (d) affective responsiveness - ability to respond to series of stimuli with feelings at the appropriate qualitative and quantitative level, (e) affective involvement - the extent to which family shows interest and appreciates the interests and activities of single members of the family, (f) control of behaviour - pattern which family accepts as acceptable behaviour in specific situations. 
Table 1. Mean scores of family functioning dimensions (Family assessment device).

\begin{tabular}{|l|c|c|c|c|}
\hline Dimension & Cut-off Score & Mean Score & Minimum & Maximum \\
\hline Problem solving & 2.20 & 2.27 & 1.00 & 3.40 \\
\hline Communication & 2.20 & $\mathbf{2 . 2 9}$ & 1.00 & 3.33 \\
\hline Roles & 2.30 & $\mathbf{2 . 4 5}$ & 1.13 & 3.50 \\
\hline Affective Responsiveness & 2.20 & 2.45 & 1.00 & 3.33 \\
\hline Affective Involvement & 2.10 & $\mathbf{2 . 5 9}$ & 1.43 & 3.86 \\
\hline Behaviour Control & 1.90 & $\mathbf{2 . 5 0}$ & 1.44 & 3.56 \\
\hline General family functioning & 2.00 & 2.38 & 1.00 & 3.75 \\
\hline
\end{tabular}

Table 2. Differences in family functioning dimensions.

\begin{tabular}{|c|c|c|c|c|c|c|}
\hline Dimension & Group & $\mathbf{N}$ & Mean Rank & $\mathbf{U}$ & $\mathbf{Z}$ & $\mathbf{P}$ \\
\hline \multirow[t]{2}{*}{ Problem Solving } & Group 1 & 310 & 324.41 & \multirow[t]{2}{*}{43736.500} & \multirow[t]{2}{*}{-1.966} & \multirow[t]{2}{*}{.049} \\
\hline & Group 2 & 310 & 296.59 & & & \\
\hline \multirow[t]{2}{*}{ Communication } & Group 1 & 310 & 338.47 & \multirow[t]{2}{*}{39379.500} & \multirow[t]{2}{*}{-3.926} & \multirow[t]{2}{*}{.000} \\
\hline & Group 2 & 310 & 282.53 & & & \\
\hline \multirow[t]{2}{*}{ Roles } & Group 1 & 310 & 315.16 & \multirow[t]{2}{*}{46604.500} & \multirow{2}{*}{-.651} & \multirow[t]{2}{*}{.515} \\
\hline & Group 2 & 310 & 305.84 & & & \\
\hline \multirow[t]{2}{*}{ Affective Responsiveness } & Group 1 & 310 & 318.67 & \multirow[t]{2}{*}{45517.000} & \multirow[t]{2}{*}{-1.146} & \multirow[t]{2}{*}{.252} \\
\hline & Group 2 & 310 & 302.33 & & & \\
\hline \multirow[t]{2}{*}{ Affective Involvement } & Group 1 & 310 & 334.53 & \multirow[t]{2}{*}{40601.000} & \multirow[t]{2}{*}{-3.356} & \multirow[t]{2}{*}{.001} \\
\hline & Group 2 & 310 & 286.47 & & & \\
\hline \multirow[t]{2}{*}{ Behaviour Control } & Group 1 & 310 & 310.85 & \multirow[t]{2}{*}{47940.500} & \multirow[t]{2}{*}{-.049} & \multirow[t]{2}{*}{.961} \\
\hline & Group 2 & 310 & 310.15 & & & \\
\hline \multirow[t]{2}{*}{ General Family Functioning } & Group 1 & 310 & 342.85 & \multirow[t]{2}{*}{38020.500} & \multirow[t]{2}{*}{-4.511} & \multirow[t]{2}{*}{.000} \\
\hline & Group 2 & 310 & 278.15 & & & \\
\hline
\end{tabular}

* Group 1 - income below the poverty threshold.

Group 2 - standard income.

The last dimension is general functioning - overall health or pathology of family [17]. The task of participant was to identify how much the statement describes his family (on scale from strongly agree - agree - disagree - strongly disagree).

\section{Results}

The results were analysed using statistical software SPSS.

As shown in Table 1, comparing average scores of individuals living below the poverty threshold with Cut-off Score, the largest differences were observed in the dimension Affective Involvement (mean score 2.59) and in the dimension Behaviour control (mean score 2.50) and in the dimension Roles (mean score 2.45).

Findings in Table 2 show that the results of Mann Whitney U test, applied to compare the average score in the dimension "communication" shows a significant difference between the group of participants living below the poverty threshold and a group of participants with a standard income $(Z=-3.926066, p=0.000)$. The average score of the group living below the poverty threshold was 338.47 , while in the group of participants with a standard income, the mean score was 282.53. In the dimension "Roles" a significant difference was not found $(\mathrm{Z}=-.651, \mathrm{p}=.515)$ between the group of participants living below the poverty threshold (mean rank 315.16) and the group of participants with a standard income (mean rank 305.84). Analysis of the results did not show a statistically significant difference $(\mathrm{Z}=1.146, \mathrm{p}=0.252)$ between participants whose income is in the range of poverty (mean rank 318.67) and participants with a standard income (mean rank 302.33) also in the dimension "Affective responsiveness". Another comparing dimension was "Affective 
Involvement". In this dimension statistically significant differences were shown $(\mathrm{Z}=-3.356$, $\mathrm{p}=0.001$ ) and group of participants living below the poverty threshold reached the mean rank 334.53, while the group of participants with standard income reached mean rank 286.47. In the dimension "behaviour control" there was not demonstrated a statistically significant difference $(\mathrm{Z}=.049, \mathrm{p}=0.961)$ between the participants whose income does not exceed the poverty threshold (mean rank 310.85) and participants with standard income (mean rank 310.15). Another dimension in which significant difference between the two groups has been demonstrated was the dimension "Problem solving" $(\mathrm{Z}=-1.966, \mathrm{p}=0.049)$. Group of participants living in poverty in this dimension reached mean rank of 324.41. The mean rank of the participants with standard income was 296.59.

Last evaluated dimension was "General Family Functioning". In this dimension appeared a significant difference in average score $(Z=-4.511, p=0.000)$ between the group of participants whose income is below the legal limit of poverty (mean rank 342.85) and the group of participants with a standard income (mean rank 278.15).

\section{Discussion and conclusion}

The importance of optimal functioning of the family system to individuals and society was already several times proven by studies and research results. Family as a whole and also the level of its functioning is affected by multiple internal and external factors. One of these factors is family income, which determines the ability of families to fulfil its economic function. It also has a fundamental impact on the fulfilment of other family functions.

If the family is unable to fulfil these functions in a satisfactory way, there is an impairment of the functioning of the family in more dimensions. This disruption has a direct impact on the lives of individual family members.

As the results of our research show, one of the most disturbed dimensions is a dimension "communication". Similar observations were found by Orthner [18] when the results of his research revealed large differences in communication skills in low-income families. Further investigations carried out in this area showed a direct effect between poor families and vocabulary development in children. This is largely influenced by the fact that most children coming from low-income home environment do not have sufficient access to formal language register. Ignorance of formal registers of language, and the inability to properly use it in their communications and then disqualify the educational process, as well as later when trying to compete in the labour market $[19,20]$. These conclusions, however, were to some extent refuted by Malin et al. [21], who pointed out that children who grow up in families struggling with economic problems do not necessarily suffer from a lack of language. His study found that in many cases the children of these families succeed, because their parents engage them in rich linguistic interchanges that foster high quality of language. Regarding communication in low-income families Payne et al. [20] pointed out that in case of distortions of the family functioning, the problem of communication culture is also present. Child without properly elected initiatives has the opportunity to acquire both modes of communication (verbal and written) in the optimal range. Especially written communication can be a problem. Payne et al. [20] describes the effect of the lack of a communication culture and the lack of incentives in the family, which causes that a child is not able to adopt the formal communication register. In the current register, however, the importance of communication consists primarily of nonverbal communication elements. Choice of words and syntax is up to second place. Written communication is a normal part of educational system and working life, therefore also children from such families often fail because their ability to formulate ideas without using nonverbal cues is limited. 
Another dimension which shows a disturbance in our research sample of low-income families is a dimension "Roles". The basic roles binding to adult family members include parental role. While belonging to one of the roles, West and Zimmerman [22] point out that they are not static constructs, but are defined by dynamic relational processes where the masculinity and femininity, as well as paternity and maternity constantly upgraded through daily interaction between people themselves. These interactions take place in the context of constantly changing gender relations and gender differentiation.

Another way to define family roles is functions that are associated with them. In relation to low-income families, particularly function of provision of means comes to the fore. This function can be linked to the economic functions of the family, such as it is described by Levická [23], Havlik and Kot' a [24] and others. The tasks in this area are largely instrumental and represent a degree of physical and financial security of the family to have the appropriate level to meet all their basic needs. However Vanková [25] points that the effect of the transformation of society in the economic sphere had a negative impact on the family. Many families, due to the factors that accompanied political and economic transformation, face crisis and are unable to fulfil their function without the help from society. This need is particularly evident in the case of families who fall into a state of deprivation and where the provision of basic living needs exceeds their financial capabilities. To the abovementioned factors which largely contribute to this condition, we can add an increase of unemployment, rising living costs etc. However, an important role in failure of the family in that capacity is also played by individual characteristics, such as the inability to effectively manage, reckless management of resources and others. Poorly fulfilled economic function of the family can have large negative implications for other functions. Ability to maintain and manage the family system is influenced by several factors. One of them is also an economic deprivation of families, which can cause serious disorganization in the family, characterized by a fragmented family structures, poorly formulated roles and disruption of the relationship. Roles in the family are often ambiguous. The mother is often unable to optimally care for the family and organize family system. She lacks the ability to define and promote the family and also to raise children. The family has certain life roles [26]. In addition to economic deprivation, among causes of failures of roles, especially parental, we can add such as a lack of maturity in carrying out the tasks related to parenthood, family ties disorders, lack of mutual help between partners - parents, to change the relationship between them, mental or physical illness, unrealistic expectations of the child or themselves, or the partner, the birth of a handicapped child, the child's separation from their mother and so on. Kameníková and Kyasová [27], also Dunovský [28] link these reasons especially with disorders in taking the parental role.

Another dimension which has been demonstrated by our research as disturbed is the functioning of behaviour control. Dimension control defines the pattern of behaviour that the family uses in managing the behaviour in three specific areas: 1. physically dangerous situations; 2. the situation involving and satisfying manifestation of psychobiological needs and instincts; 3. situations involving social behaviour among family members and with people outside the family system. In this dimension, attention is focused on the standards and rules applied by family in these three areas and the amount of freedom tolerated. This dimension deals with parental discipline over their children, as well as the norms and expectations of behaviour that adults provide to each other. Qi and Kaiser [29] showed a higher incidence of behavioural disorders in children who come from a low socio-economic status. These behaviour disorders were associated with factors, such as personality of the child, parental characteristics and socioeconomic status. In connection with the behaviour of individual members of the family and its regulation and control Dodge et al. [30], as well as 
Papp et al. 2009, [31] ) pointed out that the long-term economic pressure often leads to less effective parenting. Studies also show that prolonged exposure of parents to this pressure often utilizes corrective and punitive parent style. They often use corporal punishment to the detriment of argumentation and negotiation [32]. A number of authors [33, 34] showed correlation between long-term life of families in poverty and the incidence of violence against a partner. The behaviour of individual family members is closely related to the way in which they fulfil their roles. Disruption of this dimension was showed in our study as well. In low income families most often a conflict between parental role and working role occurs. The conflict between the two roles is caused by excessive pressure on parents when they try to be economically able to satisfy all needs of the family.

Another area, which in our research proved the impact of poverty on the family functioning, was the Affective Involvement. This dimension reflects the degree, in which the family shows interest in values and activities of others [35]. The disruption of Affective Involvement dimension was proved also by Dodge et al. [30], who showed that the poverty and its accompanied factors both reduce the ability of parents to engage in affectionate and supportive interactions with their children and increase the risk of negative or repressive behaviour. This behaviour of parents was identified as a crucial mechanism, through which poverty affects the development of children. Not only Gershoff et al. [36] but also Fine and Finchman [37] highlight the fact, that the stress caused by constant economic pressure results in instability of relationships in family. As a consequence of increased conflicts imposed by financial problems, it is not only the functioning of couple what is endangered. As the outcome of stress, the disruption of supportive parent-child relationship occurs more often.

Our research pointed to the disruption of family functioning and low-income families in several dimensions. Social work plays an important role in helping low-income families. Through early and targeted intervention it helps to rebuild not only the social functioning of individuals, but also restore the functioning of the family system. Prerequisite for effective and targeted intervention is the correct identification of problem areas in the different dimensions of family functioning and needs of low-income families.

This paper was prepared as a part of the project The Identity of Social Work in the Context of Slovakia [APVV-0524-12] funded by the Slovak Research and Development Agency.

\section{References}

[1] C. J. Johnson. Family Functioning and Intellectual Functioning in Later Life. In E. L. Grigorenko et al. (Eds) Family Environment and Intellectual Functioning: A Life-span Perspective (2009).

[2] J. A. Gullesserian. The Associations Between Child Characteristics and Family Functioning and Academic Achievement and Social Competence in Inner-City Gifted Children (2008).

[3] A. Kalil. Family Resilience and Good Child Outcomes. A Review of the Literature (2003).

[4] R. Haveman, B. Wolfe. The determinants of Children's Attainments: A Review of Methods and Findings. Journal of Economic Literature. 33(4) 1829-1878 (1995).

[5] P. Gergg, P. Machin. The Relationship Between Childhood Experiences, Subsequent Educational Attainment and Adult Labour Market Performance (1999) [online]. $<$ http://personal.1se.ac.uk/machin/pdf/lux2000.pdf $>$

[6] F. Walsh. Normal Family Processes: Growing Diversity and Complexity (2012). 
[7] E. C. Hughes. Worldview, Family Functioning, and Parenting Stress: Considerations for Behavioral Parent Training Interventions (2008).

[8] P. Klever. The multigenerational transmission of family unit functioning. American Journal of Family Therapy. 33, 253-264 (2005).

[9] S. P. Kelly. Perceptions of Family Functioning (2005).

[10] D. K. Orthner, H. Jones-Sanpei, S. Williamson. Family Strength and Income in Households with Children. Journal of Family Social Work. 7, 5-23 (2003).

[11] Zist'ovanie o príjmoch a životných podmienkach domácností EU SILC 2012. Informatívna správa štatistického úradu Slovenskej republiky. Bratislava: Štatistický úrad SR (2014) [online]. <http://slovak.statistics.sk/wps/wcm/connect/ 83ec5b46-5c4c-4dcb-a704-2b5f57a03c48/EU_SILC_2014.pdf?MOD= AJPERES $>$

[12] Národná sociálna správa ne rok 2012 (2012) <https://www.google.sk/\#psj=1 \&q $=\mathrm{Z}+\mathrm{N} \% \mathrm{C} 3 \% \mathrm{~A} 1$ rodne $\mathrm{j}+$ soci $\% \mathrm{C} 3 \% \mathrm{~A} 1 \mathrm{lnej}+\mathrm{spr} \% \mathrm{C} 3 \% \mathrm{~A} 1 \mathrm{vy}+$ na + rok $+2012+(\mathrm{ec}$. europa.eu) $++>$

[13] B. Bodnárová, D. Gergery. Jednorodičovské rodiny ohrozené chudobou: Priebežná správa z výskumnej úlohy č. 2213 "Medzitegeračná reprodukcia chudoby - vlastné empirické výskumy" (2006).

[14] D. Gerbery, B. Bodnárová, J. Filadelfiová. Životné podmienky rodín v medzigeneračnej perspektíve. In Rodina a práca. 1, 52 (2007).

[15] P. Mareš. Sociologie nerovnosti a chudoby (1999).

[16] N. B. Epstein, D. Bishop, C. Ryan, Miller, G. Keitner. The McMaster Model View of Healthy Family Functioning. In F. Walsh (Eds) Normal Family Processes. 138-160 (1993).

[17] N. B. Epstein, L. M. Baldwin, D. S. Bishop. The McMaster Family Assessment Device. Journal of Marital and Family Therapy. 9, 171-180 (1983).

[18] M. J. Austin et al. Serving Low-income Families in Poverty Neighborhoods Using Promising Programs and Practices: Building a Foundation for Redesigning Public and Nonprofit Social Services (2004).

[19] B. A. Pan et al. Maternal correlates of toddler vocabulary production in low-income families. Child Development. 76, 763-782 (2005).

[20] R. K. Payne et al. Mosty z chudoby. Stratégie pre profesionálov a komunity (2010).

[21] J. L. Malin et al. Fater-toddler communication in low-income families: The role of paternal education and depressive symptoms. Journal of the European Society on Family Relations. 155-163 (2013).

[22] H. Maříková. Pečující otcové: Příběhy plné odlišností. Sociologický časopis/Czech Sociological Review, 45(1) (2009).

[23] J. Levická. Sociálna pedagogika pre sociálnych pracovníkov (2004).

[24] R. Havlík, J. Kot'a. Sociologie výchovy a školy (2002).

[25] K. Vanková. Sociálna a ekonomická nädza a jej dopad na rodinný a spoločenský život. In Sociálna a ekonomická núdza - bezpečnost' jedinca a spoločnosti. 124-140 (2009).

[26] S. Lewis, J. Smithson. Sense of entitlement to support for the reconciliation of employment and family life. Human Relations. 54(11), 1455-1481 (2001).

[27] M. Kameníková, M. Kyasová. Ošetřovatelské diagnózy na porodním sale (2001).

[28] J. Dúnovský. Sociální pediatrie (1999).

[29] C. H. Qi, A. P. Kaiser. Behavior Problems of Preschool Children From Low-Income Families. Review of the Literature. A Journal of the Hammill Institute on Disabilities. 23(4), 188-216 (2003). 
[30] K. A. Dodge, G. S. Pettit, J. E. Bates. Socialization mediators of the relation between socioeconomic status and child conduct problems. Child Development, 65, 649-665 (1994).

[31] L. M. Papp, E. M. Cummings, M. C. Goeke-Morey. For Richer, for Poorer: Money as a Topic of Marital Conflict in the Home. Family Relations, 58(1), 91-103 (2009).

[32] R. J. Sampson, J. H. Laub. Urban Poverty and the Family Context of Delinquency: A New Look at Structure and Process in a Classic Study. Child Development, 65(2), 523-540 (1994).

[33] V. C. McLoyd. The impact of economic hardship on black families and children: Psychological distress, parenting, and socioemotional development. Child Development, 61, 311-346 (1990).

[34] P. Y. Hasima, P. R. Amato. Poverty, Social Support and Parental Behavior. Child Development. 65(2) (1994).

[35] N. Epstein, D. Bishop, S. Levin. The McMaster Model of family Functioning. Journal of Marriage and Family Counseling, 4, 19-31 (1978).

[36] E. A. Gershoff, C. Raver, M. Lennon. Income is not enough: Incorporating material hardship into models of income associations with parenting and child development. Child Development, 78, 70-95 (2007).

[37] M. A. Fine, F. D. Fincham. Handbook of Family Theories. A Content-Based Approach (2013). 